\title{
Determination of Swelling and Dimensional Stability of Some Nigerian Timber Species
}

\author{
G. C. Ajuziogu ${ }^{1}$, A. N. Amujiri ${ }^{1}$, E. U. Njoku ${ }^{1}$, C. B. Ozokolie ${ }^{1}$ and E. O. Ojua ${ }^{1 *}$ \\ ${ }^{1}$ Department of Plant Science and Biotechnology, University of Nigeria, Nsukka, Enugu State, Nigeria.
}

Authors' contributions

This work was carried out in collaboration among all authors. Authors GCA and ANA designed the study, supervised the study, managed the analyses of the study, edited the first draft of the manuscript. Authors EUN, CBO and EOO conducted the research, collected the data and managed the literature searches. Author EOO performed the statistical analysis and wrote the first draft of the manuscript. All authors read and approved the final manuscript.

Article Information

DOI: $10.9734 / A R R B / 2020 / v 35 i 130177$ Editor(s):

(1) Dr. Rishee K. Kalaria, Assistant Professor, Bioinformatics Section, Aspee Shakilam Biotechnology Institute, Navsari Agricultural University, Surat, India. Reviewers:

(1) Roger Rowell, University of Wisconsin, USA (2) M. M. V. Baig, Yeshwant Mahavidyalay, India. (3) Hoang-Dung Tran (Mr), Nguyen Tat Thanh University, Vietnam. Complete Peer review History: http://www.sdiarticle4.com/review-history/54514

Original Research Article

Received 28 November 2019

Accepted 02 February 2020

Published 14 March 2020

\section{ABSTRACT}

Aim: The absorption of moisture and dimensional distortion are the major shortcomings of wood utilization as building and furniture materials. This study was aimed at determining the moisture content, swelling ability and dimension stability of five selected timber species.

Methods: The samples were collected with the help of the Forest Ranger from the Forestry Department of Enugu State, Nigeria, attached to the Nsukka timber market. The wood samples were evaluated for moisture content change, shrinkage or swelling (\%) coefficient, amount of swelling and dimensional change.

Results: The change in moisture content across the five species was in the order of Gmelina aborea < Milicia excels < Daniellia oliveri < Alstonia bonnie < Antiaris toxicaria. At 12hrs, Gmelina aborea recorded significantly $(P<0.05)$ the highest dimension change $(46 \pm 0.70 \%)$ in the radial dimension (direction) as compared to the other species except for Antiaris toxicaria. The swelling coefficient and the amount of swelling were observed to have a strong positive correlation with the dimensional change in the sampled wood.

Conclusion: The lower swelling coefficient and the amount of swelling observed in Milicia excels among the five timber species, make it a more suitable species for industrial use. 
Keywords: Dimension distortion; radial direction; swelling coefficient; timber; wood moisture content; wood.

\section{INTRODUCTION}

The absorption of moisture and dimensional distortion are among the most important shortcomings of wood utilization as building and furniture materials. The changes in dimension that occur due to the swelling and shrinking (timber movements) of wood are major causes of both structural and visual problems in furniture [1]. Wood is a material sensitive to humidity due to the hydrophilic nature of the constituent polymers (cellulose, hemicelluloses, and lignin) of its cell wall. Therefore, the moisture content of wood varies with the changes in temperature and humidity of the surrounding. These dimensional changes in wood are caused by the variation in moisture below fiber saturation point [2]. Undesirable dimensional changes lead to cracking and twisting, shrinkage and swelling, dislodging of joints and cause significant practical problems in wood utilization for building and construction [2].

The stability in dimension is a required characteristic largely used as the condition in determining the uses of wood. The tangential and radial shrinkage of commercial species had been reported to range from 5 to $10 \%$ and 2 to $6 \%$ respectively [3]. The variability in shrinkage among wood species is as a result of the organization and structure of cells in addition to their chemical properties. Variations in the grain angle can be observed at the macroscopic scale, that is to say the wood fibres are not parallel to the trunk axis but form a helix around the tree. In some species, the helix can alternate from $S$ to $Z$ and is named interlocked grain. Also, disparities in the cell wall thickness of the wood directly impact the basic wood density at the microscopic scale. The composition of the cell wall (cellulose, lignin, extractives) and organization (angle of cellulose microfibrils helix around the cell) also affects the mechanical and physical behaviour of wood. These characteristics differ between species and are known to also vary with different life stages of the tree or in different environments.

The mechanisms of shrinkage were initially examined by Newlin and Wilson [4] and basic density has been shown to positively correlate with volumetric shrinkage $[5,6,7]$. Thus far, numerous intrinsic parameters have been shown to influence drying shrinkage. Transverse shrinkage is characterized as frequently influenced by basic density while fibre organization is known to prevail in longitudinal shrinkage. The cell wall of the wood is made of a middle lamella first, which acts as a joint linking cells, then followed by a thin primary and a thick secondary wall. The secondary cell walls of the wood are divided into three layers which include an outer $S_{1}$ layer with transversely oriented cellulose microfibrils, a thick $S_{2}$ layer with microfibrils oriented at an angle varying from 10 to $30^{\circ}$ from the cell axis, and an inner $S_{3}$ layer also with more transversely oriented microfibrils $[8,9]$.

The swelling potential is a characteristic of the cellulose microfibrils which are entrenched in a matrix of the lignin and amorphous polysaccharides $[7,10]$. The $S_{1}$ and $S_{3}$ layers are somewhat thin but play a vital function of strengthening the cell in opposition to transversal deformations (shrinkage) during drying under various humidity conditions [11]. Nonetheless, the behaviour of the $S_{2}$ layer dominates the physical properties of the cell wall due to it being much thicker than the other layers $[12,13]$. Yamamoto et al. [13] show that, in the company of basic density, microfibril angle in the $S_{2}$ layer is strongly related to the longitudinal modulus of elasticity and drying shrinkage. That is to say that low microfibrils oriented at an angle influences tangential shrinkage, while high microfibrils oriented at an angle between $30-40^{\circ}$ influences longitudinal shrinkage [7]. This study was aimed at determining the moisture content, swelling ability and dimension stability of some selected timber species and to show how long a wood withstands swelling when exposed to moisture.

\section{MATERIALS AND METHODS}

\subsection{Collection of Samples}

The wood samples of Gmelina arborea Roxb, Alstonia boonei Lam, Daniellia oliveri (Rolfe) Hutch., Antiaris toxicaria Lesch and Milicia excels (Welw.) C.C. Berg, were collected with the help of the Forest Ranger from the Forestry Department of Enugu State, Nigeria, attached to the Nsukka timber market. Preliminary identification of the samples was made following the guidelines of Titmuss and Richards [14], Anon [15], Jane [16], Desch and Dinwoodie [17], and Keay et al. [18]. A confirmatory identification of the samples was made through the microscopic studies of their sections. The 
features observed were compared with those given by Titmuss and Richards [14] and Desch and Dinwoodie [17].

Fifteen pieces of fresh specimens with a longitudinal dimension of $10 \mathrm{~cm}$ and a radial dimension of $3 \mathrm{~cm}$ were cut from representative pieces of five timbers species. The specimens were obtained at least $500 \mathrm{~mm}(20 \mathrm{in}$.) from the end of the pieces to ensure them being free from knots and other irregularities, such as bark and pitch pockets using a BOSCH JIGSAW machine (model GST 85 PBE 580W, Germany). The samples were collected from five locations in a sheet to ensure that the sample average will accurately indicate the average of the sheet.

\subsection{Determination of Moisture Content}

Each specimen was weighed using Ohaus Harvard Trip Balance (Dial-O-Gram; 2KG5LB), and placed in an oven at $105^{\circ} \mathrm{C}\left(221^{\circ} \mathrm{F}\right)$ for $18 \mathrm{hrs}$ [19]. The different specimens were then soaked in tap-water for a duration of $12 \mathrm{hrs}$ in which the weight of the specimen after soaking and excess water dried with a filter paper was measured at a $2 \mathrm{hr}$ interval. The fresh weight and the weight after drying the specimens were used to determine the percentage of moisture content before soaking using the formula:

Moisture content before soaking $(\%)=$

$$
\frac{\text { Fresh Weight-Ovendry weight }}{\text { Ovendry weight }} \times 100 \text { [19] }
$$

The moisture content after soaking was calculated as follows:

$$
\begin{aligned}
& \text { Moisture content after soaking }(\%)= \\
& \frac{\text { Fresh weight-Ovendry weight after soaking }}{\text { Ovendry weight after soaking }} \times 100
\end{aligned}
$$

While the change in moisture content was determined as follows:

$$
\begin{aligned}
& \Delta \text { Moisture Content }(\%)=\text { Moisture before soaking }- \\
& \text { moisture after soaking }
\end{aligned}
$$

\subsection{Determination of Swelling Coefficient}

The Radial length of each was then measured using a Vernier caliper after oven drying/before soaking the samples in water. The readings were measured again after soaking at an interval of $2 \mathrm{hrs}$ for $12 \mathrm{hrs}$. The swelling coefficient was then calculated using the formula:

$$
\begin{aligned}
& \Delta \quad \text { Dimension }=\mid \text { Dimension before soaking - } \\
& \text { Dimension after soaking }
\end{aligned}
$$

Percentage dimension distortion $=\Delta$ dimension $\times 100$

Shrinkage or swelling $(\%)=\frac{\Delta \text { dimension }}{\text { initial dimension }} \times 100$

\subsection{Determination of the Amounts of Shrinkage or Swelling}

The amount of shrinking or swelling which takes place as a product undergoes a change in moisture content was calculated using the formula:

$$
\Delta W=W[(S C) / 100] \times \Delta m c / 30
$$

Where:

$\Delta W=$ Change in width of the wood

$W=$ Original width of the wood

$\Delta m c=$ Change in the moisture content of the wood

$S C=$ Shrinkage or swelling coefficient [1]

Data obtained were subjected to Analysis of Variance test while significant means were separated using Duncan New Multiple Range Test (DNMRT) and Pearson correlation using IBM SPSS statistical package version 20.

\section{RESULTS AND DISCUSSION}

The duration at which wood or furniture comes in contact with liquid water is always limited to a period, i.e either during rain, or a spill on a wooden floor. This has however necessitated the understanding of how wood responds to water over short-time periods which is very essential [20]. The different timbre species responded to change in moisture content at different rates. Generally, all the species showed a constant increase in the change in moisture content as the soaking duration increased (Table 1). The change observed across the five timber in moisture content could be summarized in the order of Gmelina aborea < Milicia excels < Daniellia oliveri < Alstonia bonnie < Antiaris toxicaria with Gmelina aborea recording significantly the lowest moisture absorbing capacity (Table 1). The cellulose and hemicellulose content of wood had been attributed to being mainly responsible for moisture uptake due to them being more hygroscopic than lignin [21].

The dimension exhibited by the different timbre species was also observed and the results presented in Table 2. The result shows that irrespective of the variation observed change in 
moisture content across the five timber species, the distortion in the dimension towards the radial direction was not significantly different $(P<0.05)$ across the woods of the timber species at $2-10$ hrs soaking period. However, at $12 \mathrm{hrs}$, Gmelina aborea recorded significantly $(P<0.05)$ the highest distortion in the radial dimension as compared to the other species except for Antiaris toxicaria (Table 2).

The radial swelling coefficient similarly recorded the same trend as the changes in dimension of the woods with Gmelina aborea recording significantly $(P<0.05)$ the highest swelling coefficient $(21.11 \pm 3.54 \%)$ as compared to the other species except for Antiaris toxicaria (14.75 $\pm 3.17 \%$ ) (Table 3). Significant $(P<0.05)$ variations were also observed on the amount of swelling exhibited by these timber species at different duration soaked (Table 4). However, after soaking for $12 \mathrm{hrs}$, Antiaris toxicaria showed the highest amount with an average of $0.63 \pm$ 0.17 in while Milicia excelsa had the lowest amount of swelling $(0.15 \pm 0.05 \mathrm{in})$.

The amount of shrinkage or swelling which is an equivalent of the changes in the width of the wood is a critical feature of wood utilized in furniture making. The shrinking and swelling of wood can result in warping, checking, splitting, and loosening of tool handles gaps in strip flooring or performance problems that detract from the usefulness of the wood product. Therefore, it is important that these phenomena

Table 1. Percentage change in moisture content of wood from five timber species

\begin{tabular}{lllllll}
\hline & $\mathbf{2 h r}$ & $\mathbf{4 h r}$ & $\mathbf{6 h r}$ & $\mathbf{8 h r}$ & $\mathbf{1 0 h r}$ & $\mathbf{1 2 h r}$ \\
\hline Daniellia & 15.50 & 36.74 & 45.78 & 53.24 & 56.62 & 58.37 \\
oliveri & $\pm 4.25^{\mathrm{c}}$ & $\pm 2.30^{\mathrm{c}}$ & $\pm 2.16^{\mathrm{c}}$ & $\pm 2.05^{\mathrm{b}}$ & $\pm 1.52^{\mathrm{b}}$ & $\pm 1.31^{\mathrm{b}}$ \\
Gmelina & 1.51 & 9.92 & 12.54 & 15.13 & 14.84 & 14.66 \\
aborea & $\pm 4.43^{\mathrm{d}}$ & $\pm 3.23^{\mathrm{d}}$ & $\pm 3.09^{\mathrm{d}}$ & $\pm 3.11^{\mathrm{c}}$ & $\pm 1.89^{\mathrm{d}}$ & $\pm 1.89^{\mathrm{d}}$ \\
Alstonia & 26.79 & 43.80 & 52.93 & 59.19 & 61.00 & 61.96 \\
bonnei & $\pm 2.41^{\mathrm{b}}$ & $\pm 1.15^{\mathrm{b}}$ & $\pm 1.60^{\mathrm{b}}$ & $\pm 1.24^{\mathrm{b}}$ & $\pm 1.73^{\mathrm{ab}}$ & $\pm 2.22^{\mathrm{ab}}$ \\
Milicia & 7.91 & 14.15 & 17.73 & 20.55 & 21.56 & 21.96 \\
excelsa & $\pm 1.07^{\mathrm{cd}}$ & $\pm 0.55^{\mathrm{d}}$ & $\pm 0.55^{\mathrm{d}}$ & $\pm 0.62^{\mathrm{c}}$ & $\pm 0.86^{\mathrm{c}}$ & $\pm 0.93^{\mathrm{c}}$ \\
Antiaris & 47.65 & 75.52 & 84.89 & 93.77 & 62.69 & 55.28 \\
toxicaria & $\pm 4.38^{\mathrm{a}}$ & $\pm 3.02^{\mathrm{a}}$ & $\pm 2.82^{\mathrm{a}}$ & $\pm 2.57^{\mathrm{a}}$ & $\pm 3.19^{\mathrm{a}}$ & $\pm 2.95^{\mathrm{a}}$ \\
\hline \multicolumn{7}{c}{}
\end{tabular}

Table 2. Percentage dimension distortion exhibited by wood from five timber species

\begin{tabular}{lllllll}
\hline & $\mathbf{2 h r}$ & $\mathbf{4 h r}$ & $\mathbf{6 h r}$ & $\mathbf{8 h r}$ & $\mathbf{1 0 h r}$ & $\mathbf{1 2 h r}$ \\
\hline Daniellia oliveri & $8 \pm 0.5^{\mathrm{a}}$ & $17 \pm 0.60^{\mathrm{a}}$ & $23 \pm 0.60^{\mathrm{a}}$ & $19 \pm 0.60^{\mathrm{a}}$ & $21 \pm 0.40^{\mathrm{a}}$ & $19 \pm 0.60^{\mathrm{b}}$ \\
Gmelina aborea & $5 \pm 1.1^{\mathrm{a}}$ & $25 \pm 0.60^{\mathrm{a}}$ & $19 \pm 0.40^{\mathrm{a}}$ & $28 \pm 0.60^{\mathrm{a}}$ & $43 \pm 0.60^{\mathrm{a}}$ & $46 \pm 0.70^{\mathrm{a}}$ \\
Alstonia bonnei & $2 \pm 0.70^{\mathrm{a}}$ & $34 \pm 0.80^{\mathrm{a}}$ & $36 \pm 0.80^{\mathrm{a}}$ & $28 \pm 0.70^{\mathrm{a}}$ & $28 \pm 0.70^{\mathrm{a}}$ & $23 \pm 0.60^{\mathrm{b}}$ \\
Milicia excelsa & $1 \pm 0.90^{\mathrm{a}}$ & $18 \pm 0.40^{\mathrm{a}}$ & $29 \pm 0.70^{\mathrm{a}}$ & $30 \pm 0.90^{\mathrm{a}}$ & $30 \pm 0.70^{\mathrm{a}}$ & $20 \pm 0.60^{\mathrm{b}}$ \\
Antiaris toxicaria & $2 \pm 0.90^{\mathrm{a}}$ & $29 \pm 0.60^{\mathrm{a}}$ & $22 \pm 0.50^{\mathrm{a}}$ & $29 \pm 0.70^{\mathrm{a}}$ & $36 \pm 0.70^{\mathrm{a}}$ & $32 \pm 0.70^{\mathrm{ab}}$ \\
\hline
\end{tabular}

Table 3. The radial swelling (\%) coefficient of wood from five timber species

\begin{tabular}{|c|c|c|c|c|c|c|}
\hline & $2 \mathrm{hr}$ & $4 \mathrm{hr}$ & $6 \mathrm{hr}$ & $8 \mathrm{hr}$ & $10 \mathrm{hr}$ & $12 \mathrm{hr}$ \\
\hline Daniellia & 6.93 & 6.71 & 9.23 & 7.67 & 9.04 & 7.43 \\
\hline oliveri & $\pm 1.72^{a}$ & $\pm 1.99^{a}$ & $\pm 2.20^{a}$ & $\pm 2.43^{a}$ & $\pm 1.63^{a}$ & $\pm 2.00^{b}$ \\
\hline Gmelina & 10.82 & 10.58 & 7.68 & 11.55 & 19.13 & 21.11 \\
\hline aborea & $\pm 3.56^{a}$ & $\pm 2.87^{a}$ & $\pm 2.00^{\mathrm{a}}$ & $\pm 3.00^{a}$ & $\pm 3.26^{a}$ & $\pm 3.54^{a}$ \\
\hline Alstonia & 11.05 & 16.37 & 17.04 & 14.75 & 13.27 & 12.49 \\
\hline bonnei & $\pm 2.75^{a}$ & $\pm 3.95^{\mathrm{a}}$ & $\pm 3.73^{a}$ & $\pm 3.59^{a}$ & $\pm 3.24^{a}$ & $\pm 3.61^{\mathrm{ab}}$ \\
\hline Milicia & 9.23 & 8.06 & 13.58 & 15.19 & 13.63 & 9.12 \\
\hline excelsa & $\pm 2.65^{a}$ & $\pm 2.27^{a}$ & $\pm 3.96^{\mathrm{a}}$ & $\pm 4.69^{a}$ & $\pm 3.26^{a}$ & $\pm 3.07^{b}$ \\
\hline Antiaris & 13.50 & 11.82 & 9.86 & 12.37 & 14.69 & 14.75 \\
\hline toxicaria & $\pm 2.37^{\mathrm{a}}$ & $\pm 2.42^{a}$ & $\pm 2.14^{a}$ & $\pm 2.53^{a}$ & $\pm 2.46^{a}$ & $\pm 3.17^{\mathrm{ab}}$ \\
\hline
\end{tabular}

*significant means are represented with different alphabets along each vertical array 
Table 4. The amount of swelling (in) exhibited by wood from five timber species

\begin{tabular}{|c|c|c|c|c|c|c|}
\hline & $2 \mathrm{hr}$ & $4 \mathrm{hr}$ & $6 \mathrm{hr}$ & $8 \mathrm{hr}$ & $10 \mathrm{hr}$ & $12 \mathrm{hr}$ \\
\hline Daniellia oliveri & $\begin{array}{l}0.09 \\
\pm 0.04^{\mathrm{b}}\end{array}$ & $\begin{array}{l}0.18 \\
\pm 0.05^{b}\end{array}$ & $\begin{array}{l}0.36 \\
\pm 0.09^{\mathrm{ab}}\end{array}$ & $\begin{array}{l}0.34 \\
\pm 0.12^{\mathrm{c}}\end{array}$ & $\begin{array}{l}0.44 \\
\pm 0.10^{\mathrm{ab}}\end{array}$ & $\begin{array}{l}0.34 \\
\pm 0.08^{\mathrm{abc}}\end{array}$ \\
\hline $\begin{array}{l}\text { Gmelina } \\
\text { aborea }\end{array}$ & $\begin{array}{l}0.04 \\
\pm 0.02^{b}\end{array}$ & $\begin{array}{l}0.08 \\
\pm 0.04^{b}\end{array}$ & $\begin{array}{l}0.06 \\
\pm 0.03^{\mathrm{c}}\end{array}$ & $\begin{array}{l}0.12 \\
\pm 0.04^{b c}\end{array}$ & $\begin{array}{l}0.24 \\
\pm 0.06^{b}\end{array}$ & $\begin{array}{l}0.24 \\
\pm 0.06^{b c}\end{array}$ \\
\hline Alstonia bonnei & $\begin{array}{l}0.21 \\
\pm 0.07^{\mathrm{b}}\end{array}$ & $\begin{array}{l}0.46 \\
\pm 0.12^{a}\end{array}$ & $\begin{array}{l}0.58 \\
\pm 0.13^{a}\end{array}$ & $\begin{array}{l}0.57 \\
\pm 0.15^{\mathrm{ab}}\end{array}$ & $\begin{array}{l}0.51 \\
\pm 0.12^{a}\end{array}$ & $\begin{array}{l}0.53 \\
\pm 0.17^{\mathrm{ab}}\end{array}$ \\
\hline Milicia excelsa & $\begin{array}{l}0.06 \\
\pm 0.02^{b}\end{array}$ & $\begin{array}{l}0.09 \\
\pm 0.03^{b}\end{array}$ & $\begin{array}{l}0.19 \\
\pm 0.06^{\mathrm{bc}}\end{array}$ & $\begin{array}{l}0.24 \\
\pm 0.08^{\mathrm{bc}}\end{array}$ & $\begin{array}{l}0.22 \\
\pm 0.05^{b}\end{array}$ & $\begin{array}{l}0.15 \\
\pm 0.05^{\mathrm{c}}\end{array}$ \\
\hline $\begin{array}{l}\text { Antiaris } \\
\text { toxicaria }\end{array}$ & $\begin{array}{l}0.47 \\
\pm 0.09^{a}\end{array}$ & $\begin{array}{l}0.60 \\
\pm 0.11^{\mathrm{a}}\end{array}$ & $\begin{array}{l}0.57 \\
\pm 0.12^{\mathrm{a}}\end{array}$ & $\begin{array}{l}0.77 \\
\pm 0.15^{\mathrm{a}}\end{array}$ & $\begin{array}{l}0.61 \\
\pm 0.09^{a}\end{array}$ & $\begin{array}{l}0.63 \\
\pm 0.17^{a}\end{array}$ \\
\hline
\end{tabular}

Table 5. The correlation coefficient of between moisture, swelling and dimension distortion of wood from five timber species

\begin{tabular}{lllll}
\hline & $\begin{array}{l}\text { Moisture } \\
\text { content } \\
\text { change }\end{array}$ & $\begin{array}{l}\text { Shrinkage or } \\
\text { swelling (\%) } \\
\text { (Radial) coefficient }\end{array}$ & $\begin{array}{l}\text { Amount of } \\
\text { swelling }\end{array}$ & $\begin{array}{l}\text { Dimensional } \\
\text { change }\end{array}$ \\
\hline $\begin{array}{l}\text { Moisture content change } \\
\text { Shrinkage or swelling (\%) }\end{array}$ & -0.14 & 1 & & \\
$\begin{array}{l}\text { (Radial) coefficient } \\
\text { Amount of swelling }\end{array}$ & $0.387^{* *}$ & $0.735^{* *}$ & 1 & \\
Dimensional Change & -0.20 & $0.963^{* *}$ & $0.655^{* *}$ & 1 \\
\hline
\end{tabular}

be understood and considered when they can affect a product in which wood is used [19]. According to Eckelman [1] failure to appreciate that changes in the width of wood occur during usage may curse serious damages if the furniture is not well designed to accommodate them. Because shrinkage and swelling of wood must always be anticipated, it is imperative to design furniture to accommodate dimensional changes of the wood. Additionally, the need for moisture control and elimination of moisturerelated dimensional stability problems increases as the proposed utilization of the furniture increases [1]. As observed from the results swelling coefficient and the amount of swelling recorded a strong positive correlation with dimensional distortion in wood (Table 5).

\section{CONCLUSION}

The lower swelling coefficient and the amount of swelling observed in Milicia excels among the five timber species, makes it a more suitable species for industrial use because it would be more dimensionally stable and could be used in making durable furniture. It could be also be inferred that in order to reduce the amount of swelling in these five wood species, the wood should be dried to the proper uniform moisture content before use in manufacturing, the furniture involving these wood species should be constructed in such a way that the wood is mechanically restrained from shrinking and swelling.

\section{COMPETING INTERESTS}

Authors have declared that no competing interests exist.

\section{REFERENCES}

1. Eckelman CA. The shrinking and swelling of wood and its effect on furniture. Department of Forestry \& Natural Resources, Purdue University, West Lafayette, IN; 2020.

2. Sun $Q, Y u H$, Liu Y, Li J, Lu Y, Hunt J. Improvement of water resistance and dimensional stability of wood through titanium dioxide coating. Holzforschung. 2010;64:757-761.

DOI 10.1515/HF.2010.114

3. Walker JCF. Dimensional instability of timber. Primary Wood Processing: Springer Netherlands. 1993;95-120.

4. Newlin JA, Wilson TRC. The relation of the shrinkage and strength properties of wood to its specic gravity. Report from the Forest 
Service, US Department of Agriculture. 1919;676:60.

5. Stamm AJ. Shriking and swelling of wood. Industrial \& Engineering Chemistry. 1935; 27:401-406.

6. Stamm AJ. Surface properties of cellulosic materials. Wood Chemistry. 1952;2:691814.

7. Bossu J, Beauchêne J, Estevez Y, Duplais C, Clair B. New insights on wood dimensional stability influenced by secondary metabolites: The case of a fastgrowing tropical species Bagassa guianensis Aubl.. PLoS ONE. 2016;11(3): e0150777.

DOI:10.1371/journal.pone.0150777

8. Barnett JR, Bonham VA. Cellulose microfibril angle in the cell wall of wood fibres. Biological Reviews. 2004;79:461472.

9. Abe $\mathrm{H}$, Funada $\mathrm{R}$. The orientation of cellulose microfibrils in the cell walls of tracheids in conifers. IAWA Journal. 2005; 26:161-174.

10. Harris JM, Meylan B. The influence of microfibril angle on longitudinal and tangential shrinkage in Pinus radiata. Holzforschung. 2009;19:144-153.

11. Koponen S. Effect of wood micro-structure on mechanical and moisture physical properties. In: Butterfield BG, editor. Significance of microfibril angle to wood quality. Westport; New Zealand: University of Canterbury. 1998;348-366.

12. Donaldson L. Microfibril angle: measurement, variation and relationships: A review. IAWA Journal. 2008;29:345-386.
13. Yamamoto $H$, Sassus $F$, Ninomiya M, Gril J. A model of anisotropic swelling and shrinking process of wood. Wood Science and Technology. 2001;35:167-181.

14. Titmuss $\mathrm{FH}$, Richards $\mathrm{CH}$. Commercial timbers of the world, $4^{\text {th }}$ edition. CRC Press, Cleveland OH. 1971;351.

15. Anon. African encyclopaedia for schools and colleges. Oxford University Press, England, UK. 1974;55.

16. Jane FW. The structure of wood, $2^{\text {nd }}$ edition. Revised by $\mathrm{K}$ Wilson and DJB White. Adam Charles Black. 1962;427.

17. Desch HE, Dinwoodie JM. Timber, its structure and properties, $6^{\text {th }}$ edition. Macmillian Education, London, UK. 1981; 410.

18. Keay RWJ, Onochie CFA, Standfield DP. Nigerian treesvol. II. Federal Department of Forest Research, Ibadan, Nigeria. 1964;495.

19. Simpson WT. Drying and control of moisture content and dimensional changes. In: Wood handbook - Wood as an engineering material. Gen. Tech. Rep. FPL-GTR-113. Forest Products Laboratory, Forest Service, U.S. Department of Agriculture, Madison, WI. 1999;12(1-20).

20. Sargent R. Evaluating dimensional stability in solid wood: A review of current practice. J Wood Sci. 2019;65(36):1-11.

21. Rowell RM, Banks WB. Water repellency and dimensional stability of wood. Gen. Tech. Rep. FPL-50. Madison, WI: U.S. Department of Agriculture, Forest Service, Forest Products Laboratory. 1985:24.

(c) 2020 Ajuziogu et al.; This is an Open Access article distributed under the terms of the Creative Commons Attribution License (http://creativecommons.org/licenses/by/4.0), which permits unrestricted use, distribution, and reproduction in any medium, provided the original work is properly cited.

Peer-review history:

The peer review history for this paper can be accessed here: http://www.sdiarticle4.com/review-history/54514 